Rafat Dtużyński*

\title{
Pedagog społeczny w ujęciu profesora Aleksandra Kamińskiego
}

Nie dajcie się pospolitemu życiu, temu co Was pcha na bezdroża chamstwa, sobkowstwa i prześlizgiwania się po obowiązkach, czasy ciężkie dają najpotężniejszą okazję sercom dzielnym - dla dobra własnego i Rzeczypospolitej Polskiej, pracujcie nad sobą według długodystansowego planu ${ }^{1}$.

\section{Wprowadzenie}

Aleksander Kamiński należy do tych pedagogów, których dorobek teoretyczny i praktyczny zachowuje swoją aktualność i nieprzemijającą wartość edukacyjną dla kolejnych pokoleń zarówno młodzieży szkolnej, jak i nauczycieli. Jakkolwiek działalność opiekuńczo-wychowawcza, twórczość publicystyczna, literacka i naukowa wybitnego pedagoga związana jest z XX w., nadal pozostaje ona przedmiotem analiz i badań społeczno-pedagogicznych, stanowiąc tętniące życiem źródło inspiracji dla kolejnych pokoleń pedagogów. Świadczą o tym współczesne prace, zawierające liczne odniesienia do dorobku Aleksandra Kamińskiego, takich autorów, jak: Ewa Marynowicz-Hetka², Arkadiusz

*Absolwent studiów magisterskich, Uniwersytet Łódzki, Wydział Nauk o Wychowaniu, Katedra Pedagogiki Społecznej.

${ }^{1}$ A. Kamiński, Młodzież szkolna, „Biuletyn Informacyjny” 1943, nr 5, s. 13-14.

${ }^{2}$ E. Marynowicz-Hetka, Profil kształcenia pracowników socjalnych na poziomie wyższym, „Praca Socjalna” 1990, nr 3-4, s. 12-15. 
Żukiewicz ${ }^{3}$, Ewa Cyrańska4, Olga Czerniawska ${ }^{5}$, Mariusz Cichosz ${ }^{6}$, Mariusz Granosik $^{7}$, Krzysztof Szmidt ${ }^{8}$, Bogusław Śliwerski ${ }^{9}$, Robert Kwaśnica ${ }^{10}$ czy Lucyna Telka ${ }^{11}$.

W odniesieniu do obserwowanych zjawisk i wyzwań epoki, w jakiej działał A. Kamiński, uczony nakreślił względnie spójny obraz pedagoga społecznego, charakteryzującego się nie tylko kompetencjami zawodowymi i wiedzą merytoryczna, lecz nade wszystko określonymi kompetencjami moralnymi i etyką zawodową. Przymioty te wykorzystywał w ramach realizowanych przedsięwzięć, podejmowanych wespół z zastanymi zasobami sił ludzkich, wraz z innymi i dla dobra ogółu.

Aleksander Kamiński stał na stanowisku, iż każda epoka w historii ludzkości charakteryzuje się określoną jakością relacji społecznych, co każdorazowo przekładało się na odmienny charakter wyzwań dla następujących po sobie generacji wychowawców ${ }^{12}$. Prawidłowość tę można oczywiście odnieść do uwarunkowanych duchem epoki oczekiwań stawianych pedagogom społecznym. Jak trafnie zauważył A. Kamiński - bez względu na signum temporis - można wyodrębnić swoisty rdzeń najbardziej pożądanych kompetencji pedagoga społecznego,

${ }^{3}$ A. Żukiewicz, Praca socjalna w stużbie ludziom, Wydawnictwo Akapit, Toruń 2012; tenże, Wprowadzenie do ontologii pracy społecznej. Odniesienia do społeczno-pedagogicznej refleksji Heleny Radlińskiej, Wydawnictwo Naukowe Uniwersytetu Pedagogicznego, Kraków 2009, s. 7-8, 12-13, 82-120, 167-175; tenże, Wprowadzenie do epistemologii pracy społecznej. Odniesienia do spoleczno-pedagogicznej perspektywy poznania pracy społecznej, Wydawnictwo Uniwersytetu Łódzkiego, Łódź 2015, s. 62-70, 137-147.

${ }^{4}$ E. Cyrańska, O etosie wychowawcy wedlug A. Kamińskiego, Wydawnictwo Uniwersytetu Łódzkiego, Łódź 2004.

${ }^{5}$ O. Czerniawska, Profesor Aleksander Kamiński jakiego znałam, [w:] E. Karasiński (red.), Profesor Aleksander Kamiński. Sylwetki łódzkich uczonych, Wydawnictwo Uniwersytetu Łódzkiego, Łódź 2002, s. 34-45.

${ }^{6}$ M. Cichosz, Epoka PRL a wychowanie, [w:] H. Kubicka, M. Granosik, E. Marynowicz-Hetka (red.), Aleksander Kamiński i jego twórczość pedagogiczna. Dyskusja wobec przeszłości, wobec teraźniejszości i przyszłości, Wydawnictwo Uniwersytetu Łódzkiego, Łódź 2008, s. 202-215.

${ }^{7}$ M. Granosik, Czy Aleksander Kamiński zastuguje na krytykę, [w:] H. Kubicka, M. Granosik, E. Marynowicz-Hetka (red.), Aleksander Kamiński i jego twórczość pedagogiczna ..., s. 416-431.

${ }^{8}$ K. J. Szmidt, Człowiek jako istota psychiczna - rzecz o słabym ogniwie pedagogiki spotecznej, [w:] E. Marynowicz-Hetka, J. Piekarski, E. Cyrańska (red.), Pedagogika społeczna jako dyscyplina akademicka. Stan i perspektywy, Wydawnictwo Uniwersytetu Łódzkiego, Łódź 1998, s. $75-83$.

${ }^{9}$ B. Śliwerski, Wykład pedagogiki Aleksandra Kamińskiego do wspótczesnej teorii wychowania humanistycznego, [w:] I. Lepalczyk, W. Ciczkowski (red.), Bogactwo życia i twórczości Aleksandra Kamińskiego, Wydawnictwo Adam Marszałek, Toruń 1999, s. 215-235.

${ }^{10} \mathrm{R}$. Kwaśnica, Dwie racjonalności. O filozofii sensu ku pedagogice ogólnej, Pedagogia Plus, Poznań 2007, s. 15-19.

${ }^{11}$ L. Telka, Program profilaktyki uzależnień, Wydawnictwo Śląsk, Katowice 2003.

${ }^{12}$ A. Kamiński (red.), Funkcja wychowawcza pracy socjalnej: zbiór rozpraw z pedagogiki społecznej, Zakład Narodowy im. Ossolińskich, Wrocław 1968, s. 78. 
na które w rozumieniu uniwersalnym składają się kompetencje społeczne, merytoryczne z zakresu reprezentowanej dyscypliny, jak i określone profilem postaw etycznych - desygnaty moralne ${ }^{13}$.

W kontekście dalszych rozważań zasadne jest precyzyjne rozróżnienie pomiędzy tzw. rolą lub rolami pedagogów działających np. w ramach określonych instytucji a ujęciem sensu largo kompetencji merytorycznych oraz etyczno-moralnych, do których odwołują się np. desygnaty moralne wychowawcy lub działacza społecznego. Terminem desygnat w logice formalnej określa się ,[...] każdy konkretny obiekt pasujący do nazwy, lub ściślej - każdą rzecz oznaczaną przez dany wyraz, pojęcie lub znak"14.

Obierając perspektywę postrzeżeniową przypisaną pedagogice społecznej, nie mówimy w tym przypadku wyłącznie o roli czy rolach pedagoga społecznego wraz z szeregiem związanych z nimi pozycji ${ }^{15}$. Wskazane ujęcie, jakże często eksponowane na gruncie socjologicznym, w przypadku refleksji pedagogicznej prowadzi do zawężenia postrzegania istoty działalności pedagoga społecznego, odwołując się do paradygmatu strukturalno-funkcjonalnego. Tak zdefiniowana perspektywa postrzeżeniowa zjawiska implikuje wymóg rozpatrywania ról społecznych, związanych z nimi pozycji, obowiązków i dylematów funkcjonalnych jednostki w odniesieniu do ram przyjętych na potrzeby realizacji określonej roli - w tym wypadku roli pedagoga, co przypisuje się raczej socjologicznemu, normatywnemu postrzeganiu rzeczywistości społecznej ${ }^{16}$.

Mając na uwadze praktyczny charakter pedagogiki społecznej i pojmowanie przez A. Kamińskiego misji pedagoga społecznego, jako czynienia refleksyjnej praktyki ${ }^{17}$, odniosę się do szeregu wyzwań, instytucjonalnych form organizacji życia społecznego, opisywanych i analizowanych przez uczonego w powojennej Polsce. Odnośnie do sygnalizowanej kwestii kompetencji zarówno społecznych, merytorycznych, jak i moralnych pedagoga społecznego warto zaznaczyć, iż przynależą one do wymiaru uniwersalnego, stanowiąc wartość ponadczasową. Wobec narastających współcześnie problemów społecznych rodzi się potrzeba docenienia i wyeksponowania punktu widzenia A. Kamińskiego na kwestię aktywizowania pedagogów społecznych, inicjujących procesy zmierzające do faktycznej poprawy jakości życia społecznego.

Aleksander Kamiński, wybitny wychowawca młodzieży, harcerz, pedagog społeczny i naukowiec, w przeciagu 75 lat życia (ur. 1903 - zm. 1978) był świadkiem wielu przeobrażeń i serii brzemiennych w skutki doświadczeń, które stały

${ }^{13}$ Tamże, s. 80.

${ }^{14}$ T. Kotarbiński, Elementy teorii poznania, logiki formalnej i metodologii nauk, PWN, Warszawa 1963, s. 45.

${ }^{15}$ A. Giddens, Konsekwencje modernizacji, Stanford Press, Stanford 1990, s. 67.

${ }^{16}$ Tamże.

${ }^{17}$ A. Kamiński, Funkcje pedagogiki społecznej, w. II, PWN, Warszawa 1974, s. 12-13. 
się udziałem całego społeczeństwa polskiego. Nie sposób nie wspomnieć w tym miejscu o okresie międzywojennych prób budowy demokratycznej państwowości, hekatombie II wojny światowej, w końcu podporządkowaniu ładu społecznego, ekonomicznego i politycznego imperatywom ustrojowego dogmatyzmu autorytarnego w epoce realnego socjalizmu. Ustrój ten charakteryzowała tendencja do petryfikacji totalitarnego ładu ideologiczno-wychowawczego na drodze scentralizowanego systemu instytucji regulujących zasady życia społecznego ${ }^{18}$.

Choć pierwszy polski podręcznik dyscyplinarny autorstwa A. Kamińskiego - Funkcje pedagogiki społecznej - jest dziełem wysoce eklektycznym i uniwersalnym, to jak ma to miejsce w przypadku każdego wytworu myśli ludzkiej, powstawał on w określonych realiach temporalnych oraz społeczno-politycznych. Autor we wspomnianej pracy niejednokrotnie nawiązywał do organizacji życia społecznego, realizowanej przez wiele instytucji socjalistycznych, poszukując symptomów dysfunkcjonalności i pozorności przyświecającej im misji, tudzież wyzwań dla kolejnych pokoleń pedagogów społecznych. Co istotne, propozycje A. Kamińskiego odnośnie kompetencji pedagoga społecznego i jego posłannictwa charakteryzują się ponadczasowością, trafnością i uniwersalnością, więc pozostają aktualne bez względu na uwarunkowania gospodarcze czy polityczne. Tym bardziej zasadnym wyzwaniem dla współczesnych badaczy dyscypliny jest zatem potrzeba holistycznej prezentacji obrazu pedagoga społecznego przedstawionego przez uczonego.

\section{Służba, dzielność a zadania i obowiązki pedagoga społecznego}

„Aleksandra Kamińskiego cechowała głęboka wiara w możliwości doskonalenia człowieczeństwa. Jak twierdził, proces ten dokonuje się jednak w oparciu o poszanowanie indywidualnych wartości humanistycznych, w odniesieniu do odrębnie zdefiniowanych potrzeb każdego człowieka”19. „Ideałom oświeceniowego humanizmu służył poprzez pracę naukową, kładąc podstawy pod wychowanie «ludzi mądrych i dobrych», o których Florian Znaniecki mawiał, iż to tacy jak «[...] oni w czasach zamętu tworzą cywilizację przyszłości»"20.

Jak zauważa Mariusz Cichosz, wiele koncepcji wychowawczych okresu PRL było wynikiem dążeń politycznych ówczesnych władz, wdrażających w życie ideę państwa socjalistycznego, opartego na gospodarce scentralizowanej, pozwalającej na realizację pod ,patronatem ekonomiki marksistowskiej” bieżących potrzeb ideologicznych ustroju komunistycznego ${ }^{21}$. Rezultatem stymulacji poprzez odgórne

\footnotetext{
${ }^{18}$ O. Czerniawska, Profesor Aleksander Kamiński jakiego znałam, s. 56.

${ }^{19}$ Tamże, s. 33.

${ }^{20}$ F. Znaniecki, Nauki o kulturze, PWN, Warszawa 1971, s. 22.

${ }^{21}$ M. Cichosz, Epoka PRL a wychowanie, s. 202.
} 
dyrektywy działań ówczesnego państwa było postępujące zawłaszczanie wolności i praw obywatelskich wraz z ich wszelkimi przywilejami.

Sytuacja ta, w konsekwencji nie tylko skłaniała do refleksji, lecz wymagała zdecydowanej reakcji ze strony tych, którym wartości demokratyczne i poszanowanie praw człowieka służyły za wykładnię optymalnego funkcjonowania cywilizowanego społeczeństwa XX w. Przed pedagogami społecznymi jako wychowawcami kolejnych generacji pojawiło się zatem niezwykle pilne wyzwanie. Aleksander Kamiński w znacznym stopniu nakreślił charakter ich misji, a w konsekwencji - służby dla dobra narodu na kolejne dziesięciolecia.

Do ideałów, jakie zdaniem Aleksandra Kamińskiego powinny przyświecać działalności pedagoga społecznego, można zaliczyć m.in.: patriotyzm, obowiązkowość, szacunek dla człowieka, tolerancję, miłość, sprawiedliwość, profesjonalizm, odpowiedzialność, prawdomówność, patriotyzm. Za wartość szczególnie cenną, stanowiącą priorytetowy stymulator postaw uznawał wspomnianą służbę ${ }^{22}$. Według autora Funkcji pedagogiki społecznej pedagog społeczny powinien oddawać się jej w każdej sytuacji, czasie i miejscu. Profesor Kamiński stanowi chwalebny przykład osoby pochłoniętej służbą zarówno w harcerstwie, jako współpracownik cywilny Armii Krajowej, członek ruchu konspiracyjnego, jak i w służbie rozumianej wielowymiarowo, realizowanej w nauce i wychowaniu, na kanwie działalności literackiej, w końcu - w codziennym życiu ${ }^{23}$.

Do licznych zadań, jakie stawiał przed pedagogami społecznymi, należały również: krzewienie tolerancji, pozytywnego podejścia do zastanej rzeczywistości, animowanie zmian, inicjowanie dialogu społecznego, pomoc słabszym i wykluczonym, przyjęcie perspektywy uczestniczącego działania społecznego, charakteryzującego profesjonalnego, refleksyjnego praktyka oraz odpowiedzialności, rozumianej jako zaufane przewodnictwo ${ }^{24}$.

Aleksander Kamiński wyszczególnił także obowiązki dobrego pedagoga, traktowane jako odpowiedź na wyzwania praktycznie każdej epoki, należały do nich: 1) dyspozycyjność, organizacyjna oraz wiedza zdobyta w toku kształcenia, 2) potrzeba wolontariatu i społecznictwa, 3) wyodrębnienie poszczególnych zadań i obowiązków w nawiązaniu do terenu działania, 4) metody działań wychowawcy zgodne $z$ duchem czasu ${ }^{25}$. Jak twierdził badacz: pedagog społeczny ,[...] jest zatem czynny razem z młodymi i wśród młodych. Doradza - nie narzuca, inspiruje i sprawdza, nie wykonuje czegoś za młodzież. Kontroluje, gdyż wie, że młodzież lubi być kontrolowana przez tych, którzy jej przewodzą"26. Pedagogami,

${ }^{22}$ A. Kamiński, Teoria pracy socjalnej a pedagogika społeczna, „Biuletyn TWWP - Człowiek w Pracy i Osiedlu" 1980, nr 2-3, s. 22.

${ }^{23}$ Tamże, s. 23.

${ }^{24}$ Tamże, s. 24.

${ }^{25}$ A. Kamiński (red.), Funkcja wychowawcza pracy socjalnej..., s. 127-128.

${ }^{26}$ Tamże, s. 128. 
według A. Kamińskiego, w naturalny sposób stają się przedstawiciele wielu zawodów: milicjanci, urzędnicy, lekarze, reżyserzy czy artyści - poprzez odpowiednią pomoc w kształtowaniu postaw społecznych, współdziałania oraz wzajemnych świadczeń. Przede wszystkim są nimi jednak pracownicy socjalni ${ }^{27}$.

Metodą pracy pedagoga społecznego, odwołującą się do umiejętności przewodzenia grupie oraz towarzyszenia w jej strukturach 'powinności do działania', jest tzw. metoda pracy z grupa. Zdaniem A. Kamińskiego w tym przypadku najistotniejsze jest, aby lider czynił dokładnie to samo, czego wymaga z osobna od każdego członka grupy. Jednakże działanie takie okazuje się aplikatywnym w praktyce, jedynie w odniesieniu do grup tworzących się spontanicznie i dobrowolnie $^{28}$. Jak twierdził badacz, w przypadku pracy z grupa

[...] wychowawca (pracownik socjalny) ma przed sobą zespolony przez wspólne zadanie zbiór osób; wiąże go nie tylko „dialog” z pojedynczymi członkami tej zbiorowości - jego talent wychowawczy wyraża się w umiejętnościach przewodzenia lub przodowania grupie i takiego oddziaływania na grupę, aby na straży zadań i zwyczajów sugerowanych przez wychowawcę - stał nie tylko on, lecz także członkowie grupy ${ }^{29}$.

Aleksander Kamiński fascynował się także procesem narodzin i wzrastania w człowieku dzielności. Jak twierdził, „prawdziwa dzielność zawsze idzie w parze $\mathrm{z}$ cnotą. Zawiera w sobie umiar, panowanie nad sobą i sprawiedliwość”. Mawiał również, iż: „dzielność jest fundamentem charakteru, a tylko ludzie z charakterem mogą zbudować lepszy świat", przyczyniając się do promowania i reprezentowania postawy „człowieka z charakterem”, której ów wybitny wychowawca młodzieży oczekiwał od swoich studentów - przyszłych pedagogów społecznych ${ }^{30}$.

W tym przypadku podstawowe zadanie pedagoga czy instruktora sprowadza się do odpowiedzi na fundamentalne pytanie: jak pomagać ludziom, aby rozwijać w nich dzielność? Jak twierdził A. Kamiński, nadrzędny cel edukacji do dzielności

[...] winien być zorientowany na kształtowanie całego człowieka. Dwie podstawowe funkcje edukacji to rozwijanie osobowości i uspołecznienie zostały uzupełnione przez funkcję trzecią, którą stanowi przygotowanie do wkroczenia w rzeczywistość ekonomiczną ${ }^{31}$.

Realizując przyjęty model edukacyjny, cenną umiejętnością pedagoga społecznego jest kształtowanie i realizacja poszczególnych funkcji związków młodzieży, do których zalicza się: funkcję towarzyską (opartą na koleżeństwie), funkcję wczasową, funkcję ideologiczną - łączoną z zadaniami wychowawczymi, funkcję przygotowawczą do działalności naukowej, literackiej, wojskowej i innej. Poprzez

\footnotetext{
${ }^{27}$ A. Kamiński, Funkcje pedagogiki społecznej..., s. 89, 299.

${ }^{28}$ Tamże, s. 272-274.

${ }^{29}$ Tamże, s. 221.

${ }^{30}$ A. Kamiński (red.), Funkcja wychowawcza pracy socjalnej..., s. 142.

${ }^{31}$ Tamże, s. 140.
} 
współpracę młodych ludzi zrzeszonych w związkach, wspólnie rozwiązujących rozliczne problemy, stawiających czoła wyzwaniom, dokonuje się jednocześnie hartowanie ich charakterów, uszlachetnienie człowieczeństwa. Tak realizowana „praca nad samym sobą staje się jednocześnie zaczynem dzielności”32.

\section{Indywidualny przypadek w środowisku lokalnym Wychowanie do starości}

W odniesieniu do wyzwań związanych z przesłankami psychologicznymi aktywizacji pedagogów na płaszczyźnie terapeutyczno-wychowawczej A. Kamiński upatrywał swoistego zagrożenia ze strony psychologii wychowawczej33. Obawiał się, iż tzw. „praca z przypadkiem” opierać się będzie wyłącznie na zaleceniach rozumienia człowieka, bezwarunkowego akceptowania jednostki taką jaką jest, wczucia się w jego sytuację - jak postulowała Mary Richmond ${ }^{34}$. Uczony sygnalizował wyraźnie potrzebę przekształcania środowiska pacjenta, kompensowania lokalnych, środowiskowych braków, spożytkowania potencjału licznych placówek i urządzeń istniejących w środowisku. Zdaniem uczonego, pedagog społeczny w pierwszej kolejności ,[...] powinien szukać przyczyn ludzkich trudności poza samą jednostką" ${ }^{35}$. Wobec tego każdy człowiek jest indywidualnym, niepowtarzalnym bytem, z misternie utkaną sferą przeżyć, tworzącą subiektywny świat znaczeń, symboli, sieci interakcji. Aleksander Kamiński proponował pedagogowi społecznemu, by był zdolny łączyć refleksję nad każdym przypadkiem ze światem społecznym i jego skomplikowanymi uwarunkowaniami ${ }^{36}$.

Jak zauważył - pośród licznych poradni zdrowotnych, zatrudniających wykwalifikowany personel zajmujący się zindywidualizowanym informowaniem i poradnictwem, możemy wyróżnić ,pporadnie przeciwweneryczne, przeciwalkoholowe, zdrowia psychicznego czy świadomego macierzyństwa" ${ }^{37}$. W przypadku kontaktów z pacjentami - oprócz personelu medycznego - pedagog społeczny, biegły w ,prowadzeniu indywidualnych przypadków, umiejący stosować wychowawczą terapię $\mathrm{i}$ - niestety, niejednokrotnie uczyć zachowania się w najprostszych dziedzinach higieny i profilaktyki" - może oferować liczne zabiegi opiekuńczo-wychowawcze, poniekąd wspomagając zabiegi medyczne ${ }^{38}$.

${ }^{32}$ A. Kamiński, Środowisko wychowawcze - klopoty definicyjne, „Ruch Prawniczy, Ekonomiczny i Socjologiczny" 1974, nr 4, s. 142-143.

${ }^{33}$ K. J. Szmidt, Człowiek jako istota psychiczna ..., s. 77.

${ }^{34}$ M. Richmond, Social Diagnosis, Harvard University - Collection Development Department Russell Sage Foundation, New York 1917, s. 26.

${ }^{35}$ A. Kamiński, Funkcje pedagogiki społecznej..., s. 259.

${ }^{36}$ Tamże, s. 260-261.

${ }^{37}$ Tamże, s. 360-361.

${ }^{38}$ Tamże, s. 361. 
Aleksander Kamiński uważał również, iż wyzwaniem dla pedagoga społecznego w każdej epoce jest niesienie uświadamiającego przesłania w kwestii swoistości ujęcia i różnic kulturowego rozumienia płciowości człowieka, co z perspektywy współczesnego dyskursu nad równouprawnieniem oraz rolą płci kulturowej było propozycją prekursorską i godną odnotowania ${ }^{39}$.

Według badacza, uwzględniając wyzwania współczesności oraz obserwowaną tendencję starzenia się społeczeństw uprzemysłowionych ulegającą nasileniu, kolejną domenę zainteresowań pedagoga społecznego powinna stanowić gerontologia ${ }^{40}$. Jak twierdził

wyłonienie się i szybki rozwój gerontologii społecznej jest skutkiem „rewolucji populacyjnej”, ogarniającej cały świat i wyrażającej się w dożywaniu późnej starości przez coraz większy odsetek ludzi [...]. Zatem przeciętny człowiek starszy jest dziś młodszy niż dawniej, jest sprawny mimo swoich 60, 65, 70 lat a stylem swojego życia wciąż wiąże się z młodością ${ }^{41}$.

Wiodącą rolę w aktywizacji osób w wieku podeszłym uczony przypisywał określonym środowiskom wychowawczym o charakterze zarówno lokalnym, jak i globalnym, czyli: rodzinie, szkole, osiedlom mieszkaniowym, stowarzyszeniom społecznym, np. Polskiemu Towarzystwu Gerontologicznemu, którego był współtwórcą̨2 . Aleksander Kamiński uważał, iż bez względu na wymogi polityczno-gospodarcze określonej epoki zasadne jest, aby szczególnym zainteresowaniem pedagoga społecznego cieszyło się środowisko lokalne. Posiada ono następujące cechy: materialną bazę zaspakajania potrzeb i interesów odczuwanych i reprezentowanych przez większość grup oraz jednostek żyjących na danym terytorium, dominujący typ kultury i tradycji, wokół którego organizuje się życie społeczności, charakterystyczną więź społeczną oraz komunikację interpersonalną. W dalszej kolejności wyszczególniamy w owym środowisku ideały i wzory życia przyjmowane oraz naśladowane w sposób spontaniczny przez daną zbiorowość, zdolność formalnych elementów więzi do kreowania nieformalnych zobowiązań, a co się z tym wiąże - wysoki poziom kontroli społecznej, sankcje, wstyd i honor ${ }^{43}$. Aleksander Kamiński twierdził, iż

[...] pracownicy służb społecznych, posiadający zdolności organizatorskie i administracyjne, podejmują zadania społeczno-wychowawcze na rzecz ożywienia i kulturalnego podniesienia [ku rozwojowi - przyp. R. D.] społeczności lokalnych ${ }^{44}$.

${ }^{39}$ A. Kamiński, Częstsze u chłopców niż u dziewczat niedostosowanie do szkoty i rodziny, [w:] tenże, Studia i szkice pedagogiczne, PWN, Warszawa 1972, s. 147.

${ }^{40}$ A. Kamiński, Funkcje pedagogiki społecznej..., s. 365.

${ }^{41}$ Tamże, s. 311.

${ }^{42}$ Tamże, s. 368-369.

${ }^{43}$ A. Kamiński, Samorzqd młodzieży jako metoda wychowawcza, Państwowe Zakłady Wydawnictw Szkolnych, Warszawa 1985, s. 42-43.

${ }^{44}$ A. Kamiński, Funkcje pedagogiki społecznej..., s. 231. 
Uczony wskazywał również na rolę poziomu zaangażowania społeczności lokalnej w ,poczynania melioracyjne”, stanowiące istotne „kryterium powodzenia podejmowanych działań" ${ }^{45}$. Do sfery zadań pracownika socjalnego w odniesieniu do kierowania działaniami na rzecz holowania ku rozwojowi społeczności lokalnej należą:

koordynowanie poczynań zainteresowanych instytucji i osób, inspirowanie instytucji i osób o słabszej wyobraźni społecznej, dopomaganie w dobrym układaniu się stosunków międzyludzkich [...], propagowanie realizowalnych poczynań [A. Kamiński, mając na względzie osiąnnięcia epoki przywołuje jako przykłady: radiowęzeł, gazetkę osiedlową, tablice ogłoszeń, zebrania sprawozdawcze; dziś powiedzielibyśmy: Internet, komunikatory, blogi, poczta elektroniczna (e-mail), e-biuletyny itp. - przyp. R. D.], inicjowanie badań dodatkowych, weryfikujących, dopełniających i aktualizujących lustrację społeczną, hospitowanie i inspekcjonowanie realizowanych przez poszczególne placówki poczynań, ocenianie stanu i wyników pracy socjalnej w środowisku lokalnym, w końcu - konsultowanie (osób) zwracających się po porady ${ }^{46}$.

\section{Praca socjalna, pracownik socjalny}

Kolejnym wyzwaniem dla pedagoga społecznego - bardzo szeroko rozważanym przez A. Kamińskiego zarówno na kanwie teoretycznej, jak i praktycznej - jest praca socjalna rozumiana jako działanie społeczne zasadzające się na rozpoznawaniu warunków rzeczywistości materialnej oraz niematerialnej, w których zachodzi pilna potrzeba ratownictwa, pomocy i opieki ${ }^{47}$. W odniesieniu do historii rozwoju pracy socjalnej możemy wyróżnić okres pionierski, którego czołowymi przedstawicielami byli: Edward Abramowski, Ludwik Krzywicki, Stanisław Rychliński, którzy współdziałali z Heleną Radlińską -twórczynią teorii pracy socjalnej w Polsce. Jak przypomina A. Kamiński, dzieło H. Radlińskiej Egzamin z pedagogiki spolecznej podejmuje m.in. interdyscyplinarność pedagogiki społecznej oraz rolę pracy społecznej ${ }^{48}$.

Okres kolejny przypada na lata 70. i 80. XX w., w którym pedagogika społeczna oraz polityka społeczna zaczynają odgrywać coraz donioślejszą rolę. Postępowało zatem - jak to miał w zwyczaju określać badacz - „olbrzymienie licznych organizacji”"49. Aleksander Kamiński opisywał rolę pracownika socjalnego w nowej rzeczywistości. Był współtwórcą pierwszych programów nauczania dla przyszłych pracowników i szkół pracy socjalnej. Postrzegał ową profesję niezwykle szeroko - jako obejmującą wszelkie działania na rzecz osób wymagających

${ }^{45}$ Tamże, s. 234.

${ }^{46}$ Tamże, s. 238.

${ }^{47}$ A. Kamiński, Podstawowe pojęcia pedagogiki społecznej w pracy socjalnej, Instytut Wydawniczy CRZZ, Warszawa 1976, s. 64-65.

${ }^{48}$ A. Kamiński, Funkcje pedagogiki społecznej..., s. 20-22.

${ }^{49}$ Tamże, s. 136, 262. 
pomocy. Do działań tych zaliczał „kompensację społeczną ${ }^{50}$, opiekę ${ }^{51}$, pomoc wspierającą rozwój ${ }^{52}$, służbę społeczną ${ }^{53}$ i pracę socjalną" ${ }^{54}$. Postulował, aby pedagog społeczny identyfikował politykę społeczną jako ,siostrzaną dyscyplinę względem pedagogiki społecznej”, upatrując w niej głównego katalizatora działań o charakterze formalno-organizacyjnym ${ }^{55}$.

Ewa Marynowicz-Hetka przypomina również, iż istota kształcenia do pracy socjalnej - znajomość teorii psychologicznych, ułatwia pracownikowi socjalnemu wniknięcie $\mathrm{w}$ tzw. mikroświat przeżyć emocjonalnych podopiecznego. Znajomość teorii psychosocjologicznych przyspiesza zatem stworzenie schematu analizy poszczególnych zjawisk psychospołecznych - a w końcu może stanowić niezwykle cenne źródło technik i narzędzie działania społecznego ${ }^{56}$.

Aleksander Kamiński dostrzegał ponadto szerokie pole dla aktywności pedagoga społecznego w nowoczesnym modelu służby społecznej. W dwudziestoleciu międzywojennym RP wzorowała się na tzw. modelu zachodnim, natomiast w PRL następowało niepohamowane olbrzymienie instytucjonalne, uwidaczniała się również ignorancja oddolnej inicjatywy filantropijnej, co według A. Kamińskiego było zasadniczym błędem tamtej epoki. Zatem nowoczesny model służby społecznej odnosił się do „unaukowienia opieki, integracji zabiegów wokół komórki rodzinnej i środowiska lokalnego, pedagogizowania czynności opiekuńczych, uzawodowienia pracowników opieki oraz szerszego akcentowania profilaktyki opiekuńczej”s7.

Aleksander Kamiński zauważał również, iż w okresie PRL kategoria społecznikostwa została całkowicie podporządkowana panującemu ustrojowi społeczno-politycznemu. Na przykład powszechnie realizowane „dobrowolne czyny społeczne” czy programy i postulaty „dobrowolnego uczestnictwa”, „czyn społeczny” „dobrowolnie" sprzęgały cały naród do realizowania określonego celu. Wszelkim związkom o podłożu filantropijnym nadawano konotację niemal ,siłaczkowego męczeństwa"s8.

Kolejnym polem aktywności pedagoga społecznego, będącym niezwykle ważnym elementem funkcjonowania większości społeczeństw, okazała się instytucja współcześnie rozumianego wolontariatu. Jak twierdzi Stanisław Gawroński, idee i wartości wolontariatu to postawienie człowieka w centrum zainteresowań, zwrócenie bacznej uwagi na potrzebujących, szacunek dla ludzi, bezinteresowność. Niezbędne do osiagnięcia tego celu są również: wiara w sens służby, dzielenie własnego

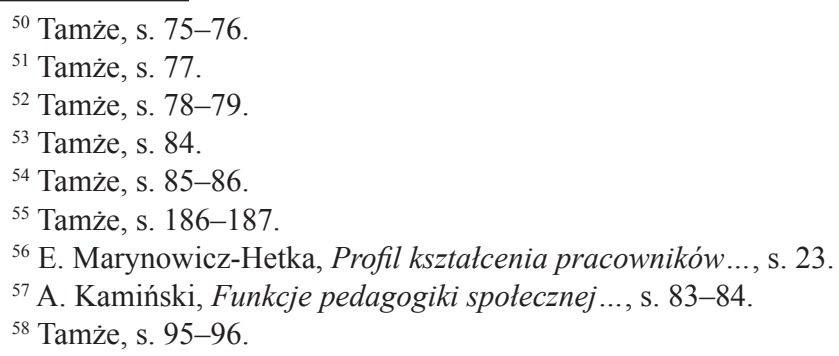


istnienia $\mathrm{z}$ istnieniem innych, stymulowanie instytucji publicznych i domaganie się od państwa praw dla słabszych, a ponadto wyprzedzanie działań i odpowiedzi państwa na pilne potrzeby, tworzenie odmiennej świadomości u osób bezrefleksyjnie podchodzących do trudnego losu innych, przekazywanie sensu człowieczeństwa w służbie społecznej ${ }^{59}$. Według A. Kamińskiego pedagog społeczny łączy

[...] świadczenia rzeczowe z zabiegami wychowawczymi, w postaci cierpliwego wysłuchania „pacjenta”, psychicznego nań oddziaływania, służenia poradą oraz zabiegami zmierzającymi do wyciszenia niepokojów podopiecznego, do oddziaływań na rzecz przystosowania do siebie jednostek i rodzin [...] do tego, aby każdy własnym wysiłkiem dążył do wybrnięcia z kłopotów i zwiększenia szans sukcesu życiowego ${ }^{60}$.

Warto zauważyć, iż przed rokiem 1989 termin „wolontariat” został zawłaszczony przez tzw. „,czyn społeczny”, niemający niczego wspólnego z dobrowolnością. Ówczesny Kodeks pracy mówił wprost, iż ,pojęcie wolontariatu jest obce socjalistycznym stosunkom pracy i stanowi formę ukrytego wyzysku pracownika przez pracodawcę" 61 . W tym kontekście A. Kamiński jako pedagog społeczny wybiegał myślami, jak to ujęła Olga Czerniawska, do ,jutra” i ,pojutrza”, zaś wizja społeczeństwa przyszłości, którą propagował, okazała się bliska myśli chrześcijańskiej. Dobro ogółu powinno zatem przeważać nad partykularnymi interesami uprzywilejowanych jednostek lub elit, sankcjonujących w imię trwałych korzyści istniejące status quo, oparte na nierównościach i wyzysku społeczeństwa, nad którym sprawują władzę.

Aleksander Kamiński uważał, iż warto, aby pedagog społeczny przejawiał głęboką troskę o przyszłość moralną i intelektualną polskiego społeczeństwa. Zdawał sobie sprawę nie tylko z degrengolady lat wojennych, lecz także zgubnych manowców ustroju pozornej równości - zarówno komunizmu, jak i konsumpcyjnych pułapek kapitalizmu. Dostrzegał szereg zagrożeń w nas samych, potrafił napiętnować słabości i grzechy ciężkie charakteru narodowego Polaków, czyli brak poczucia wartości dobra wspólnego (pro publico bono), partykularyzm, zazdrość, politykierstwo, osłabioną dzielnośćc6.

\section{Kultura masowa, czas wolny i wczasowanie}

Jako pedagog społeczny - wnikliwy obserwator epoki dominacji mass mediów i wynikających z nich zagrożeń - A. Kamiński twierdził, iż tzw. kultura masowa stanowić może realne zagrożenie dla młodzieży, gdyż promuje powierzchowne

${ }^{59}$ S. Gawroński, Ochotnicy miłości bliźniego - przewodnik po wolontariacie, Biblioteka Więzi, Warszawa 1999, s. 27-28.

${ }^{60}$ Tamże, s. 302.

${ }^{61}$ Tamże, s. 34.

${ }^{62}$ O. Czerniawska, Profesor Aleksander Kamiński jakiego znałam, s. 34. 
wartości życia, bezrefleksyjność, bezkrytyczność, a w efekcie kształtuje jedynie niepohamowany pęd konsumpcyjny. Jak twierdził uczony, „kultura masowa, budząca sprzeciw wychowawcy wobec tych jej postaci, które schlebiają najniższym gustom - zagłuszając wśród ukulturalnianych kręgów społecznych wątłe zainteresowania tym, co wartościowsze - jest zarazem tą postacią kultury, która dociera do najszerszych mas $[\ldots]^{\prime \prime 63}$. Wobec imperatywu oddziaływania mediów, emitujących ten typ przekazu ku szerokim rzeszom odbiorców, traci ostatecznie na znaczeniu jakakolwiek forma kontroli społecznej, co powoduje, iż w konsekwencji liczy się tylko autonomia jednostki, częstokroć budowana kosztem ładu społecznego ${ }^{64}$. Aleksander Kamiński proponował również, aby pedagog społeczny, w odniesieniu do wpływu tego typu kultury na charakter i świadomość zwłaszcza najmłodszych członków społeczeństwa, wykazał się szczególną wrażliwością, hermeneutycznym namysłem nad długofalowymi skutkami oddziaływania mediów na młodzież. Według niego kompetentny wychowawca powinien zaproponować alternatywne i atrakcyjne formy zabawy i wypoczynku, pozwalające na uniknięcie pułapek zagrożeń medialnych. Szczególne niebezpieczeństwo stanowią te zagrożenia, które prowadzą do desensytyzacji, przemiany czasu wolnego w pusty czas wolny i bezkrytyczne naśladownictwo zachowań agresywnych, często afirmowanych w czasach anomii normatywnej i relatywizmu normatywnego ${ }^{65}$. Zauważalne jest, iż przesłanie do pedagogów społecznych sformułowane przez A. Kamińskiego nabiera znaczenia i aktualności, jeśli weźmiemy pod uwagę szereg niebezpieczeństw czyhających na najmłodszych użytkowników oferty współczesnych e-mediów, zwłaszcza szerokiej kafeterii gier elektronicznych (RPG) oraz Internetu ${ }^{66}$.

W odniesieniu do realiów życia społecznego w epoce zauważył, iż wiejskie klubokawiarnie stanowiły doniosłe osiagnięcie pracy kulturalno-oświatowej, koncentrując w sobie specyficzne siły społeczne, integrując społeczność lokalną wokół procesów realizacji jej podstawowych oczekiwań. W tym aspekcie badacz dostrzegał szerokie możliwości aktywizacji kompetentnego personelu edukacyjno-wychowawczego, co według jego słów miało ,[...] pomóc w osiąnnięciu światowego poziomu funkcjonowania poszczególnych placówek" ${ }^{67}$.

Pozytywnym wymiarem oferty domów kultury była również obecność poradni metodycznych, gdzie wykwalifikowany personel udzielał fachowych wskazówek pracownikom świetlic, klubów usytuowanych w rejonie samego domu kultury, co pozwalało na stymulowanie ich działalności, a jednocześnie umożliwiało

${ }^{63}$ A. Kamiński, Funkcje pedagogiki społecznej..., s. 62.

${ }^{64}$ Tamże, s. 58-59.

${ }^{65}$ Tamże, s. 60.

${ }^{66}$ J. Izdebska, Rodzina, dziecko, telewizja. Szanse wychowawcze i zagrożenia telewizji, Wydawnictwo Signus, Białystok 1996, s. 77.

${ }^{67}$ A. Kamiński, Funkcje pedagogiki społecznej..., s. 171-172, 177. 
doskonalenie zawodowe pracowników kulturalno-oświatowych w ramach kursów specjalistycznych ${ }^{68}$. Realizując działania prewencyjne, pedagog społeczny może potraktować takie instytucje, jak kluby, koła zainteresowań czy domy kultury , ,...] jako ośrodki prewencji wychowawczej, ale równie uprawomocnione jest ujmowanie tych instytucji przez andragogów jako ośrodki oświaty ciagłej, a przez polityków - jako teren wychowania politycznego" "69. Oczywiście na tej kanwie profesjonalnie wykwalifikowani pedagodzy społeczni mogli skutecznie wdrażać idee, które swój matecznik miały w twórczości Heleny Radlińskiej czy jej wybitnych kontynuatorów - Ireny Lepalczyk oraz Aleksandra Kamińskiego.

W nawiązaniu do możliwości wykorzystania kompetencji społeczno-organizacyjnych pedagoga społecznego oraz wiedzy merytorycznej z zakresu dyscypliny A. Kamiński zwrócił też uwagę na rolę kolonii wakacyjnych oraz innych form wczasowania. Ja twierdził - obozy młodzieżowe w epoce PRL doczekały się co prawda ogromnego rozkwitu, jednak (w opinii badacza) w odniesieniu do realizowanych przez nie zadań oświatowo-wychowawczych można było odnotować szereg rażących uchybień personelu opiekuńczo-wychowawczego, sprowadzających się częstokroć do braku zainteresowania, kontroli i odpowiedzialności za przebieg życia obozowiczów ${ }^{70}$. Powołując się na rezultaty badań sondażowych, autor Funkcji pedagogiki społecznej dowodził, iż

personel wychowawczy, rekrutowany spośród nauczycieli i zawodowych wychowawców, bywa znużony przebywaniem wśród dzieci, pozbawiony uciechy ze wspólnych z nimi zabaw i zajęć, skłonny do odosobniania się od dzieci nawet podczas „fizycznego” przebywania wśród nich. Niektóre dość istotne zajęcia realizowane są pobieżnie, „formalnie”, bez serca i ożywczej myśli znalezienia dla nich ponętnej postaci, np. gimnastyka poranna, cisza poobiednia itp. ${ }^{71}$.

Uczony wskazywał ponadto na pozytywną funkcję społeczno-wychowawczą domów wczasowych, zaznaczając, iż ich idea bazowała na wzorcach wypoczynkowych zamożniejszych przedstawicieli społeczeństwa kapitalistycznego, co implikowało pilną potrzebę zaadaptowania do tego wzorca przedstawicieli rodziny robotniczej ${ }^{72}$. Zarówno w przypadku obozów młodzieżowych, jak i ośrodków wczasowo-wypoczynkowych pedagog społeczny miałby odgrywać wiodącą rolę w stymulowaniu zachowań integracyjnych. Polegałaby ona m.in. na przedłożeniu szerokiej kafeterii propozycji konstruktywnego spędzania czasu wolnego, co w zamierzeniu miało przyczynić się nie tylko do niwelowania napięć psychicznych, wynikających z monotonnego trybu obowiązków w pracy i szkole. Efektem oddziaływania stymulowanego przez wychowawcę mogłoby się stać rozbudzenie

\footnotetext{
${ }^{68}$ Tamże, s. 195.

${ }^{69}$ Tamże, s. 303.

${ }^{70}$ Tamże, s. 221.

${ }^{71}$ Tamże, s. 220-221.

${ }^{72}$ Tamże, s. 222-223.
} 
potrzeby wszechstronnego i długofalowego rozwoju osobistego oraz nawyku współuczestnictwa w nauce kompetencji społecznych w szerszym gronie ${ }^{73}$.

Sygnalizowana przez A. Kamińskiego potrzeba urozmaicenia form wykorzystania czasu wolnego wydaje się szczególnie znamienna w odniesieniu do funkcjonowania we współczesnym społeczeństwie konsumpcyjnym, w którym dominują skomercjalizowane, zawłaszczone przez korporacje rozrywkowe, formy masowej zabawy i rekreacji ${ }^{74}$. W przekonaniu A. Kamińskiego jednym z zadań pedagoga społecznego powinno być dążenie do upowszechnienia i organizowania życia społecznego $\mathrm{w}$ podobnych miejscach ${ }^{75}$. W wielu krajach europejskich do dnia dzisiejszego z dużym powodzeniem wykorzystuje się przesłanki tego typu form aktywizacji społecznej.

Jak zauważył A. Kamiński, fakt „upowszechnienia umiejętności czytania, pisania oraz liczenia, można poczytywać za imponujące osiagnięcie PRL, przypadające na lata 1949-1951 r." ${ }^{.76}$. Zatem kolejnymi logicznie uzasadnionymi krokami powinny być: wprowadzenie warstw upośledzonych w uczestnictwo do życia kulturalnego ogółu społeczeństwa oraz utrwalanie potrzeby kształcenia przez całe życie. Kreśląc wizję świetlanej przyszłości, rysującą się przed wspomnianą formą edukacji, A. Kamiński twierdził:

[...] szczególnie silnie oddziała (ona) na programy i metody szkolne; na programy - przez odciążenie ich od wiedzy encyklopedycznej, dostępnej coraz bardziej dzięki środkom masowego przekazu, coraz umiejętniej apelujących do zainteresowań i aspiracji młodzieży; na metody kształcenia - wskutek zapełnienia godzin uzyskanych dzięki redukcjom encyklopedyzmu lekcyjnego i wszelkich przeładowań programu - przez metody nauczania aktywnego i problemowego, pobudzającego myślenie twórcze, innowacyjne, rozwiązujące napotykane zagadnienia, skłaniające do samokształcenia $[\ldots]^{77}$.

Znaczącą rolę we wdrażaniu tego typu działań, pozwalających na inkluzję przedstawicieli poszczególnych grup społecznych w procesie edukacji i samokształcenia na różnych poziomach, mogliby odgrywać odpowiednio przygotowani pedagodzy społeczni, współpracujący z placówkami edukacyjnymi ${ }^{78}$.

Aleksander Kamiński postulował, aby obowiązkiem nauczycieli klas początkowych stała się konieczność otoczenia dzieci przejawiających trudności w nauce szczególną troską opiekuńczą, wzmacnianą jednocześnie celowymi zabiegami wyrównawczymi, zależnymi od indywidualnych potrzeb każdego wychowanka ${ }^{79}$. Ponadto nowoczesna szkoła nie może być, jak to ujął A. Kamiński, ,[... [ szkołą nudy dla dzieci

\footnotetext{
73 Tamże, s. 223.

74 Tamże.

75 Tamże, s. 224.

76 Tamże, s. 318.

77 Tamże, s. 321.

78 Tamże, s. 342-343.

79 Tamże, s. 344-345.
} 
zdolnych, rozleniwiających umysły, a przez to paczącą charaktery najwartościowszych intelektualnie uczniów, musi się stać szkołą pobudzającą wysiłki intelektualne i moralne tej kategorii dzieci i młodzieży"80. Zlekceważenie tego problemu implikuje proces pojawienia się grupy dzieci nieprzystosowanych do życia. Zatem warto, aby wśród kompetencji pedagoga społecznego pojawiła się zdolność do uruchomienia ośrodków poradnictwa, zajmujących się opieką zwłaszcza w okresie adaptacyjnym oraz w trudniejszych okresach życia młodzieży. Tutaj uczony dostrzegał kolejne szanse dla aktywizacji pedagogów społecznych, którzy profesjonalnie pokierowaliby procesami korekcyjno-edukacyjnymi, wdrażanymi w tego typu placówkach ${ }^{81}$.

\section{Demokracja i edukacja permanentna}

Aleksander Kamiński w następujący sposób rozumiał pojęcie kształcenia ciagłego pedagogów społecznych - oświata to struktura złożona z trzech komponentów: kształcenia szkolnego - od przedszkola do uczelni wyższej; kształcenia równoległego w instytucjach i placówkach pozaszkolnych - domy kultury, kluby zainteresowań, świetlice, związki i stowarzyszenia młodzieży oraz kształcenia ludzi dorosłych w rozlicznych szkołach i uczelniach ${ }^{82}$.

Kolejnym zagadnieniem, które stanowiło przesłanie A. Kamińskiego dla pedagogów społecznych, była potrzeba upowszechnienia tzw. edukacji permanentnej. Sprowadzała się ona do zajęć rozwojowych, podejmowanych z pobudek indywidualnych, obejmujących szereg zainteresowań w celu doskonalenia się w danej dziedzinie kultury duchowej lub materialnej, w poczynaniach społecznych lub w kulturze fizycznej. Działania tego typu wymagają

[...] osobistego zaangażowania pedagoga, co jest samo w sobie spójne z podstawowym postulatem rozwojowym pedagogiki społecznej, jako nauki o człowieku działającym w środowisku, jednak ukierunkowanej na aktywność praktyczną ludzkiego podmiotu, opartej na aksjonormatywnym kryterium działania ${ }^{83}$.

Wymowne i ponadczasowe jest też przesłanie uczonego dotyczące afirmacji demokracji w obliczu ustroju totalitarnego, co można interpretować jako kolejne zadanie stawiane pedagogom społecznym. A. Kamiński odwoływał się zwłaszcza do kompetencji moralnych wychowawców, takich jak: prawda, pochwała niezależnej myśli i twórczości, liberalnie umiarkowane podejście do rzeczywistości, poczucie osobistej odpowiedzialności za wychowanie swoich

\footnotetext{
${ }^{80}$ Tamże, s. 113.

${ }^{81}$ Tamże, s. 378-379, 388-389.

82 Tamże, s. 320.

83 Tamże, s. 323.
} 
podopiecznych ${ }^{84}$. Można stwierdzić, iż (za M. Montessori) pedagog miał każdorazowo towarzyszyć podopiecznym w rozwoju, nie tracąc pogodnego usposobienia, będąc sprawiedliwym, życzliwym, afirmując umiłowanie zawodu, zapał i służąc pomocą tak wychowankom, jak i kolegom ${ }^{85}$.

Jak twierdził wybitny pedagog:

[...] to nie konstytucja, nie same normy i prawa ustrojowe, uwarunkowania polityczne, władza albo charakter reform - nie masy ludzkie i granice państwowe, stanowią o wielkości jednostki i narodu, ale to człowiek per se, istota ludzka ze swoim potencjałem do kształtowania własnego charakteru, możliwościami samorozwoju i samowychowania - zapewnia tryumf w walce ze wszelkim totalitaryzmem ${ }^{86}$.

Aleksander Kamiński już w dobie okupacji hitlerowskiej propagował wizję państwa i społeczeństwa demokratycznego. Stworzył antytotalitarny model humanistyki, był protagonistą ustroju demokratycznego państwa polskiego we współczesnym rozumieniu, odwołując się do takich wartości, jak wolność, równość i parlamentaryzm ${ }^{87}$. W takim duchu wychowywał, jako nauczyciel akademicki, kolejne pokolenia swoich studentów.

Wobec powyższego pedagog społeczny powinien być przekonany, iż dla zaistnienia państwa demokratycznego niezbędne jest, aby zasady demokracji objęły oświatę, życie społeczne i gospodarcze, w przeciwnym razie takowy ustrój będzie miał wszelkie cechy zakłamania pseudodemokratycznego, tak charakterystycznego dla społeczeństwa „demokracji ludowej”88. Wychowawca kierujący się poczuciem misji i ufnością lokuje swoje pedagogiczne nadzieje właśnie w demokracji. Powodowany doświadczeniem w skali mikro (zuchostwo, uharcerzenie społeczeństwa) ma on świadomość tkwiącego w tym właśnie ustroju ogromnego potencjału do zaangażowania społecznego, hartowania charakteru, wzmacniania woli, kształtowania dzielności, lojalności, postaw obywatelskich i autentycznej dyscypliny społecznej ${ }^{89}$.

Pedagog społeczny przywiązuje znaczącą wagę do istoty oraz znaczenia dla rozwoju demokratyzacji wszelkich zjawisk, społeczności i ruchów lokalnych, także tzw. „naszej szkoły lokalnej”, odgrywającej doniosłą rolę w rozwoju społeczności lokalnej. Aleksander Kamiński prezentował stanowisko, według którego wychowawca ,[...] upatruje możliwości kształtowania postaw demokratycznych

${ }^{84}$ A. Kamiński, Co to jest demokracja?, [w:] A. Janowski, Być dzielnym i umieć się różnić. Szkice o Aleksandrze Kamińskim, Wydawnictwo Naukowe PWN, Warszawa 1992, s. 17.

${ }^{85}$ M. Montessori, Domy dziecięce: metoda pedagogiki naukowej stosowana w wychowaniu najmłodszych dzieci, Wydawnictwo Akademickie „Żak”, Warszawa 2005, s. 77.

${ }^{86}$ A. Kamiński, Środowisko wychowawcze - kłopoty definicyjne, s. 16.

${ }^{87}$ Tamże, s. 17.

${ }^{88}$ Tamże, s. 19.

${ }^{89}$ Tamże, s. 18. 
i patriotycznych, na gruncie społecznym, oświatowym oraz w gremiach osób reprezentujących instytucje odpowiedzialne za funkcjonowanie państwa"90.

Wymowne i jakże aktualne okazuje się też przesłanie A. Kamińskiego dla młodzieży, zamieszczone na łamach „Biuletynu Informacyjnego”:

[...] nie dajcie się wojennemu życiu, temu co Was pcha na bezdroża chamstwa, sobkowstwa i ślizgania się po obowiązkach, czasy ciężkie dają najpotężniejszą okazję sercom dzielnym - dla dobra własnego i Rzeczypospolitej Polskiej, pracujcie nad sobą według długodystansowego planu ${ }^{91}$.

Jak zauważył Bogusław Śliwerski, gdyby ekstrapolować te słowa sprzed ponad 70 lat na dzisiejsze realia, pedagog społeczny mógłby współcześnie apelować - „nie dajcie się konsumpcyjnemu stylowi życia, co wciaga nas na bezdroża chamstwa, sobkowstwa i ślizgania się po obowiązkach. Pamiętajmy wszyscy o tym, iż każdego dnia toczymy naszą małą wojnę o przyszłe jutro, nie może nam zabraknąć dzielności oraz odwagi"'92!

\section{Pedagog w procesie wychowania}

Ideały wychowawcze, którym hołdował A. Kamiński oraz kształtowany na ich podstawie obraz pedagoga społecznego, emanują również z kolejnych rozdziałów beletrystyki, a także dzieł o charakterze historycznym jego autorstwa. Zjawisko to można dostrzec nie tylko w przypadku dokonań literackich A. Kamińskiego, lecz charakteryzuje ono w nie mniejszym stopniu twórczość J. Korczaka czy H. Radlińskiej. W przypadku wskazanych autorów wysoki poziom artystyczny samego tekstu towarzyszy przewodnictwu idei etycznych i myśli humanistycznej ${ }^{93}$.

Aleksander Kamiński nawiązuje do procesu wychowania, który dokonuje się w różnych sytuacjach życiowych, podczas wszystkich etapów życia człowieka. Jego zdaniem zasadne jest, aby pedagog społeczny opowiadał się za poszerzeniem tradycyjnego ,[...] środowiska wychowawczego (rodzina, szkoła, placówki opieki nad dzieckiem) o poradnie świadomego macierzyństwa, schroniska turystyczne, szpitale, dziecięce grupy podwórkowe, muzea, redakcje, zespoły artystyczne, zakłady pracy i społeczność sąsiedzką i osiedlową"94.

W odniesieniu do przedstawionego stanowiska - według A. Kamińskiego - , ,...] zadaniem pedagogów społecznych jest nasycenie nowego typu mieszkań i osiedli wzorcami kulturalnymi urządzeń i zachowań, ale fundamentem jest tu polityka mieszkaniowa, zapewniająca należyte minimum powierzchni

\footnotetext{
${ }^{90}$ Tamże, s. 21.

${ }^{91}$ A. Kamiński, Młodzież szkolna, s. 13.

${ }^{92}$ B. Śliwerski, Wykład pedagogiki Aleksandra Kamińskiego..., s. 234.

${ }^{93}$ Tamże, s. 405.

${ }^{94}$ A. Kamiński, Funkcje pedagogiki społecznej..., s. 118-119.
} 
mieszkaniowej [...]"95. W kontekście stymulowania relacji interpersonalnych w zakładach pracy zadaniem pedagoga społecznego byłoby ,[...] tworzenie atmosfery sprzyjającej identyfikowaniu się członków załogi z przedsiębiorstwem i jego celami" 96 .

Aleksander Kamiński wyróżnił trzy typy działań wychowawczych, w przypadku których kontakt oparty jest na indywidualnym stosunku wychowawcawychowanek. Wówczas wychowanie zespołowe w grupie może być stymulowane przez pedagoga. Możemy mówić także o procesie wychowania przebiegającym dzięki dążeniu do ulepszania środowiska jego własnymi siłami ${ }^{97}$. Szczególnie istotnym dla pedagoga społecznego jest trzeci typ wychowania, który obejmuje człowieka oraz instytucje umożliwiające wychowanie, zaś rolę wiodącą w tym przypadku odgrywa środowisko życia i proces jego przetwarzania ${ }^{98}$.

Oddziaływanie wychowawcze ma szczególne znaczenie w funkcjonowaniu najważniejszej z grup pierwotnych, jaką jest rodzina. Dla zdecydowanej większości - zarówno dzieci, jak i dorosłych - pozostaje ona, jak to ujął Aleksander Kamiński: „[...] podstawowym zespołem wspólnoty życia”. Jest zatem wspólnotą emocjonalną, gdzie w toku kolejnych lat życia trwa proces wyrównywania poglądów oraz ocen na gruncie wzajemnych relacji interpersonalnych. Można zauważyć, iż rozmaite konflikty występujące pomiędzy członkami rodziny zostają poddane procesom swoistej akomodacji, zmierzając do wypracowania rozwiązań konstruktywnych, petryfikujących więzi rodzinne ${ }^{99}$.

Jak twierdził A. Kamiński - pedagog społeczny wyznacza sobie zadanie ,„[...] przekształcenie rodziny naturalnej, która jest naturalnym środowiskiem życia w rodzinę stanowiącą środowisko wychowawcze, czyli zespół bodźców ukierunkowanych intencjonalnie na wartości społeczno-moralne tworzących ją osób"100.

Według A. Kamińskiego podstawowym wyzwaniem, jakiego nie można lekceważyć, jest dla każdego wychowawcy dążenie do uczynienia z rodziny swojego sprzymierzeńca. Kompetentny pedagog społeczny wyzwanie takie postrzega jako „[...] propozycję wnikania w społeczno-wychowawczą problematykę rodzin dla wspomagania sił ukierunkowujących ją ku pomyślnemu rozwiązywaniu trudności”'101. Pomoc tzw. rodzinie problemowej, w której spotykamy się z trudnościami współżycia, z tendencją do, jak to ujął A. Kamiński, ,poślizgu w kierunku marginesów społecznych", stanowi odrębne zadanie wychowawcze. Zatem pedagog społeczny ,[...] odpowiedzialny za pomoc takiej grupie rodzinnej, dopomaga jej

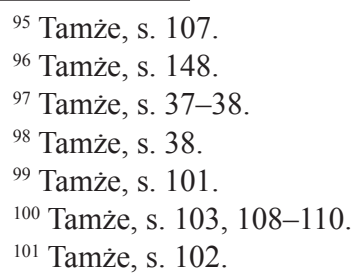


członkom w rozwikłaniu swoich rodzinnych trudności, zarówno poprzez inicjatywy kompensacyjne (wyrównujące braki), jak i przez rozmowy, wydobywające „siły rodziny $[\ldots]$...102.

Formułując swoje przesłanie do przyszłych pokoleń pedagogów społecznych, w trosce o dobro dzieci, ofiar wojny i przeobrażeń państwa polskiego po roku 1945, A. Kamiński eksponował (podobnie jak J. Korczak) potrzebę tworzenia domów dziecka opartych na wzorze prawidłowo funkcjonującej, pełnej ciepła rodziny, co przekładałoby się na odnajdywanie najtrafniejszych rozwiązań wychowawczych. Wobec powyższego pedagog społeczny, pragnąc być kompetentnym w swoim posłannictwie, zazwyczaj uwzględnia kilka czynników, warunkujących przebieg procesu organizowania środowiska wychowawczego, należą do nich: „rozpoznawanie potrzeb dzieci, młodzieży, rodziny, sąsiadów, otoczenia ze szkoły oraz wyszukiwanie i określanie sił środowiska przy pomocy osób wartościowych moralnie i społecznie" ${ }^{103}$.

W przypadku dzieci wychowywanych w domach dziecka A. Kamiński zwracał uwage, iż częstokroć zatrudniona w nich kadra pedagogiczna, ma do czynienia $\mathrm{z}$, ,[...] dziećmi specjalnymi, przejawiającymi zaburzenia emocjonalne i motywacyjne, wynikające z braku więzi rodzinnej, a wychowanie w domu dziecka często tych zaburzeń nie tylko nie leczy, ale je pogłębia"104.

Jedynie odpowiednio wykwalifikowany personel, złożony z osób o profilu moralnym, zbliżonym do wzorca empatycznego pedagoga-przyjaciela, jest gotowy do stworzenia pokrzywdzonym przez los dzieciom namiastki rodzinnego szczęścia, którego z różnych przyczyn nie mogły zaznać w rodzinach pochodzenia.

\section{Metody pracy pedagoga a stowarzyszenia młodzieży w środowisku lokalnym}

Aleksander Kamiński zaproponował również trzy odrębne metody pracy pedagoga społecznego z zastanym środowiskiem społecznym. Stosował metodę indywidualnego przypadku, w której wiedza życiowa, nauka o człowieku i środowisku wspomagają wzajemne przystosowanie się jednostki oraz środowiska. Pedagog społeczny mógłby w tym celu wykorzystać diagnozę społeczną, pozwalającą na rozpoznanie przyczyn ich nasilenia, opracowanie planu postępowania ukierunkowanego na praktyczne korygowanie środowiska, a także na postępowanie wychowawcze lub prowadzenie przypadku drogami rewalidacji ${ }^{105}$. Do podstawowych zasad stosowania tej metody należą: ,zaakceptowanie jednostki taką

\footnotetext{
102 Tamże, s. 277.

103 Tamże, s. 167.

104 Tamże, s. 228.

105 Tamże, s. 225.
} 
jaka jest, wiara w człowieka, budowanie mostu życzliwości, dążenie do nastawienia jednostki, aby sama zechciała skorygować swoje życie"106.

Kolejną metodą stosowaną przez uczonego była tzw. metoda pracy grupowej, w ramach której oddziałuje się na jednostkę za pośrednictwem małej grupy. Celem tej pracy jest, jak to ujął badacz, „uczynienie grupy zespołem wychowawczym”, zaś sama praca z grupą polega na wysłuchaniu zwierzeń, inicjowaniu mentalnego aktu krytyki, oddziaływaniu psychoterapeutycznemu. Praca pedagoga społecznego nastawiona jest $\mathrm{w}$ tym przypadku na ,[...] niesienie ratunku i opieki nad jednostką nieprzystosowaną społecznie"107.

Trzecią metodą wykorzystywaną przez A. Kamińskiego było organizowanie społeczności lokalnej, czyli ,środowiska naturalnego grupy ludzi, którą łączy bliskość zamieszkania" ${ }^{108}$. W tym przypadku poszczególnych działań nie prowadzi się dla społeczności, lecz poprzez społeczność i wspólnie z nią. Dlatego pedagog społeczny ma „[...] koordynować poczynania, inicjować badania dodatkowe, hospitować i inspekcjonować poczynania oraz oceniać rezultaty działań oraz udzielać konsultacji bieżących" 109 .

Stabilizacja poczynań organizujących społeczności lokalne przez pedagoga społecznego może mieć kilka postaci. Należą do nich m.in.: ,[... ] objęcie kierownictwem poczynań przez grupę, objęcie kierownictwem poczynań przez samorząd osiedlowy, w końcu powołanie w tym celu specjalnej organizacji"110. Tak rozumiane kierownictwo społeczno-wychowawcze, według A. Kamińskiego, nieodzownie ,[...] wiąże się z ukierunkowaniem osiedlowych procesów wychowawczych głównie na potrzeby postrzegane przez szkołę, a więc przede wszystkim na potrzeby dzieci i młodzieży"111. To również zbiór kolejnych kompetencji organizacyjno-społecznych, jakimi (według uczonego) powinna charakteryzować się skuteczna działalność pedagoga społecznego. W kontekście uwarunkowań epoki A. Kamiński uważnie obserwował rozwój funkcji rzeczywistej stowarzyszeń, a zwłaszcza funkcji sąsiedztwa z wyboru, funkcji integrującej jednostki ze środowiskiem szerszym, w końcu funkcji ekspresyjnej ${ }^{12}$.

Na łamach pierwszego polskiego podręcznika dydaktycznego uczony Funkcje pedagogiki społecznej zawarł wyraźną krytykę, jak to ujął „olbrzymienia ideowo-politycznego" 113 charakteru związków młodzieżowych w epoce realnego socjalizmu, co przekładało się na skrzywienia ideologiczne i upolitycznienie

\footnotetext{
106 Tamże, s. 226.

107 Tamże, s. 269-271.

108 Tamże, s. 278-280.

109 Tamże, s. 280-281.

110 Tamże, s. 284.

111 Tamże, s. 137.

112 Tamże, s. 155-157.

113 Tamże, s. 159-160.
} 
wszelkich form działalności młodzieży. Olbrzymienie instytucji publicznych oraz stowarzyszeń społecznych, zdaniem autora podręcznika, jest specyficznym procesem, który

[...] sprzyja etatyzacji stowarzyszeń oraz zarówno w olbrzymiejących stowarzyszeniach, jak i w instytucjach publicznych - powoduje ich biurokratyzowanie, schematyzowanie pracy, zanik bezpośrednich kontaktów międzyludzkich. Życie społeczne broni się przed zesztywnieniem i zwiędnięciem przez aktywizowanie najniższych komórek organizacyjnych - jako naturalnych wspólnot podstawowych - opierając się na zainteresowaniach, dążeniach i emocjach ich członków oraz odpowiednio przygotowanych pracowników ${ }^{114}$.

Pedagog społeczny, uwrażliwiony na negatywne konsekwencje tego typu praktyk, w ramach swoich kompetencji wskazywałby na doniosłą rolę samorządności jako sposobu organizacji życia społecznego. Pamiętając oczywiście o jego wymiarze obywatelskim, na poziomie młodzieżowym mógłby wykorzystać naturalny zapał i energię uczniów do organizowania samorządów uczniowskich ${ }^{115}$. Samorządy tego typu A. Kamiński opisywał już w 1965 r. na łamach pracy Samorzad młodzieży jako metoda wychowawcza ${ }^{116}$.

\section{Refleksje końcowe}

W kontekście wyzwań stawianych przez autora Funkcji pedagogiki społecznej kolejnym pokoleniom pedagogów społecznych, warty odnotowania jest fakt, że chociaż działalność naukowa i pedagogiczna Aleksandra Kamińskiego przypadała na lata 1945-1978, czyli na kolejne dekady realnego socjalizmu, to szereg spostrzeżeń dotyczących kompetencji i związanych z nimi zadań pedagoga społecznego zyskało na aktualności po przełomie transformacyjnym 1989 r. Co więcej, wobec szeregu wysublimowanych oczekiwań współczesności, w której częstokroć system wartości i pozycja człowieka jest definiowana w kategoriach stricte komercyjnych, wiele spostrzeżeń badacza zyskuje na aktualności, a ich aplikowanie w celu przekształcania środowiska życia społecznego wydaje się potrzebą wysoce priorytetową.

Reasumując zawarte w artykule rozważania, znamienne wydaje się, iż wartości moralne szczególnie cenione w zawodzie nauczyciela nie powinny się radykalnie zmieniać, ale zostać przedefiniowane i dostosowane do współczesnych, dynamicznych procesów dziejowych. Jak twierdzi Robert Kwaśnica - w świecie, w którym ,[...] dominuje pluralizm nurtów poznawczych, filozoficznych, kulturowych (często wzajemnie wykluczających się), wartości które są zrębem i ostoją

\footnotetext{
${ }^{114}$ Tamże, s. 311.

${ }^{115}$ Tamże, s. 334.

${ }^{116}$ A. Kamiński, Samorzad młodzieży jako metoda wychowawcza, s. 46.
} 
postępowania pedagoga, powinny wyrastać z człowieka i manifestować swoją rolę w procesie katalizowania rozwoju osoby ludzkiej"117. Konieczność redefinicji obranych ideałów służy temu, aby niezmienne, a zatem tradycyjnie rozumiane człowieczeństwo nie było osobnym komponentem, ale spójnym elementem cywilizacyjnej machiny dziejowej.

Z obecnej perspektywy dalekowzroczność propozycji A. Kamińskiego jest tym bardziej czytelna w odniesieniu do potrzeby akceptacji przez większość społeczeństwa świata zastanego w jego wieloaspektowości i multikulturowej formie. Stanowi ona przeciwieństwo dychotomicznej, binarnej logiki aplikowanej niejednokrotnie pod parawanem ,,poprawności ideologicznej” przez zewnętrzne czynniki polityczne czy ekonomiczne. Dążą one częstokroć do ugruntowania w naszej świadomości wzorców moralnych, odwołując się do autorytarnych, jednowymiarowych sądów o charakterze ideologicznym, stanowiących zarzewie destruktywnych postaw, zaczynem których bywa afirmacja nietolerancji i ksenofobii.

Według Olgi Czerniawskiej dictum A. Kamińskiego i jednocześnie jedną z najdonioślejszych misji, którą pedagog społeczny powinien realizować przez całe swoje życie, jest krzewienie ideału społecznego, według którego żylibyśmy tak, ,abyśmy umieli się pięknie różnić" ${ }^{118}$. Mimo upływu 38 lat od śmierci wybitnego pedagoga, tak trudno jest wcielić te słowa w życie...

\section{Bibliografia}

Cichosz M., Epoka PRL a wychowanie, [w:] H. Kubicka, M. Granosik, E. Marynowicz-Hetka (red.), Aleksander Kamiński i jego twórczość pedagogiczna. Dyskusja wobec przeszłości, wobec teraźniejszości i przyszłości, Wydawnictwo Uniwersytetu Łódzkiego, Łódź 2008.

Cyrańska E., O etosie wychowawcy według A. Kamińskiego, Wydawnictwo Uniwersytetu Łódzkiego, Łódź 2004.

Czerniawska O., Profesor Aleksander Kamiński jakiego znałam, [w:] E. Karasiński (red.), Profesor Aleksander Kamiński. Sylwetki łódzkich uczonych, Wydawnictwo Uniwersytetu Łódzkiego, Łódź 2002.

Gawroński S., Ochotnicy miłości bliźniego - przewodnik po wolontariacie, Biblioteka Więzi, Warszawa 1999.

Giddens A., Konsekwencje modernizacji, Stanford Press, Stanford 1990.

Granosik M., Czy Aleksander Kamiński zastuguje na krytykę, [w:] H. Kubicka, M. Granosik, E. Marynowicz-Hetka (red.), Aleksander Kamiński i jego twórczość pedagogiczna. Dyskusja wobec przeszłości, wobec teraźniejszości i przyszłości, Wydawnictwo Uniwersytetu Łódzkiego, Łódź 2008.

Izdebska J., Rodzina, dziecko, telewizja. Szanse wychowawcze i zagrożenia telewizji, Wydawnictwo Signus, Białystok 1996.

Kamiński A. (red.), Funkcja wychowawcza pracy socjalnej: zbiór rozpraw z pedagogiki społecznej, Zakład Narodowy im. Ossolińskich, Wrocław 1968.

${ }^{117}$ R. Kwaśnica, Dwie racjonalności..., s. 76.

${ }^{118}$ O. Czerniawska, Profesor Aleksander Kamiński jakiego znałam, s. 59. 
Kamiński A., Co to jest demokracja?, [w:] A. Janowski, Być dzielnym i umieć się różnić. Szkice o Aleksandrze Kamińskim, Wydawnictwo Naukowe PWN, Warszawa 1992.

Kamiński A., Częstsze u chłopców niż u dziewczq̨ niedostosowanie do szkoły i rodziny, [w:] tenże, Studia i szkice pedagogiczne, PWN, Warszawa 1972.

Kamiński A., Funkcje pedagogiki społecznej, w. II, PWN, Warszawa 1974.

Kamiński A., Młodzież szkolna, „Biuletyn Informacyjny” 1943, nr 5.

Kamiński A., Narodziny dzielności: dwadzieścia opowiadań dla młodzieży. Ilustracje Władysław Czarnecki, Oficyna Księgarska, Warszawa 1947.

Kamiński A., Osiedle mieszkaniowe jako środowisko wychowawcze, [w:] I. Lepalczyk, W. Pawłowska (red.), Teoria i organizacja pracy środowiskowej w osiedlu mieszkaniowym, Wydawnictwo Naukowe UW, Warszawa 1970.

Kamiński A., Podstawowe pojęcia pedagogiki społecznej w pracy socjalnej, Instytut Wydawniczy CRZZ, Warszawa 1976.

Kamiński A., Samorzad młodzieży jako metoda wychowawcza, Państwowe Zakłady Wydawnictw Szkolnych, Warszawa 1985.

Kamiński A., Środowisko wychowawcze - kłopoty definicyjne, „Ruch Prawniczy, Ekonomiczny i Socjologiczny" 1974, nr 4.

Kamiński A., Teoria pracy socjalnej a pedagogika społeczna, „Biuletyn TWWP - Człowiek w Pracy i Osiedlu" 1980, nr 2-3.

Kotarbiński T., Elementy teorii poznania, logiki formalnej i metodologii nauk, PWN, Warszawa 1963.

Kwaśnica R., Dwie racjonalności. O filozofii sensu ku pedagogice ogólnej, Pedagogia Plus, Poznań 2007.

Marynowicz-Hetka E., Profil ksztatcenia pracowników socjalnych na poziomie wyższym, „Praca Socjalna" 1990, nr 3-4.

Montessori M., Domy dziecięce: metoda pedagogiki naukowej stosowana w wychowaniu najmłodszych dzieci, Wydawnictwo Akademickie „Żak”, Warszawa 2005.

Oakley A., Sex, Gender And Society, Temple Smith, London 1972.

Richmond M., Social Diagnosis, Harvard University - Collection Development Department Russell Sage Foundation, New York 1917.

Szmidt K. J., Człowiek jako istota psychiczna - rzecz o słabym ogniwie pedagogiki społecznej, [w:] E. Marynowicz-Hetka, J. Piekarski, E. Cyrańska (red.), Pedagogika społeczna jako dyscyplina akademicka. Stan i perspektywy, Wydawnictwo Uniwersytetu Łódzkiego, Łódź 1998.

Śliwerski B., Wykład pedagogiki Aleksandra Kamińskiego do współczesnej teorii wychowania humanistycznego, [w:] I. Lepalczyk, W. Ciczkowski (red.), Bogactwo życia i twórczości Aleksandra Kamińskiego, Wydawnictwo Adam Marszałek, Toruń 1999.

Telka L., Program profilaktyki uzależnień, Wydawnictwo Śląsk, Katowice 2003.

Wojtyła K., Osoba i czyn oraz inne studia antropologiczne, Wydawnictwo KUL, Lublin 2000.

Znaniecki F., Nauki o kulturze, PWN, Warszawa 1971.

Żukiewicz A., Praca socjalna w stużbie ludziom, Wydawnictwo Akapit, Toruń 2012.

Żukiewicz A., Wprowadzenie do epistemologii pracy społecznej. Odniesienia do społeczno-pedagogicznej perspektywy poznania pracy społecznej, Wydawnictwo Uniwersytetu Łódzkiego, Łódź 2015.

Żukiewicz A., Wprowadzenie do ontologii pracy społecznej. Odniesienia do społeczno-pedagogicznej refleksji Heleny Radlińskiej, Wydawnictwo Naukowe Uniwersytetu Pedagogicznego, Kraków 2009. 